Universidade de Brasília

Centro de Excelência em Turismo

OS PROGRAMAS DE ALEITAMENTO MATERNO E A

QUALIDADE DO LEITE OFERTADO A CRIANÇAS

PRETERMO PELOS BANCOS DE LEITE HUMANO: UMA

REVISÃO.

Karla Lisboa Ramos

Luiz Antônio Borgo

Brasília, DF, Abril, 2004. 


\author{
UNIVERSIDADE DE BRASÍLIA \\ Centro de Excelência em Turismo \\ Curso de Especialização em Qualidade em Alimentos
}

\title{
OS PROGRAMAS DE ALEITAMENTO MATERNO E A QUALIDADE DO LEITE OFERTADO A CRIANÇAS PRETERMO PELOS BANCOS DE LEITE HUMANO: UMA REVISÃO.
}

\section{Karla Lisboa Ramos}

\author{
Luiz Antônio Borgo \\ Mestre \\ Wilma Maria Coelho de Araújo \\ Doutora \\ Monografia apresentada ao Centro de \\ Excelência em Turismo da Universidade de \\ Brasília como requisito parcial para obtenção \\ do certificado de Especialista em Qualidade \\ em Alimentos
}

Brasília, DF, Abril, 2004. 


\section{Ramos, Karla Lisboa.}

Os programas de aleitamento materno e a qualidade do leite ofertado a crianças pretermo pelos bancos de leite humano : uma revisão / Karla Lisboa Ramos. - Brasília, 2004. $52 \mathrm{f}$.

Monografia (especialização) - Universidade de BrasíliaCentro de Excelência em Turismo.

Área de concentração: Alimentos.

Orientador: Luiz Antônio Borgo.

1. Aleitamento materno 2. Banco de leite humano 3. Qualidade microbiológica. 


\section{AGRADECIMENTOS}

Gostaria de externar meus sinceros agradecimentos a todos os professores, funcionários e colegas do curso de Especialização em Qualidade de Alimentos que participaram direta ou indiretamente na elaboração desta monografia.

A nossa coordenadora, Prof. Dra. Wilma Araújo, pela atenção dispensada e carinho com que nos atendia, além da oportunidade e incentivo em realizar mais este trabalho.

Ao meu querido amigo e orientador, Prof. Ms. Luiz Antônio Borgo, que sempre esteve acessível para discutir e amadurecer minhas questões sobre o tema escolhido.

Aos meus queridos pais, Wilson e Magaly, os quais amo muito, por terem me apoiado e estimulado a finalizar mais este título.

Ao meu querido e amado Rodrigo, que se tornou meu noivo no decorrer deste curso e sempre esteve ao meu lado, mesmo nos dias mais exaustivos.

Ao meu irmão Wilson, que apesar de não estar aqui durante a realização deste curso, sempre me motivou a me qualificar; à minha cunhada Cláudia e minha gorda, Paula, pelos momentos de descontração.

Ao meu irmão William, pelo carinho e socorro nos trabalhos dos módulos de Administração.

À Deus, por me abençoar em todos os dias da minha vida. 


\section{RESUMO}

Atualmente, o aleitamento materno, no Brasil, é uma prática bem sucedida devido aos programas oficiais de incentivo ao aleitamento materno que se iniciaram na década de 80 e perduram até hoje. A partir da mobilização dos profissionais da área da saúde, dos órgãos governamentais e não governamentais e da sociedade, foi possível alcançar, no final da década de 80, um aumento do período de amamentação. Mesmo assim, ainda existe o desmame precoce na classe média e, principalmente, na população de baixa condição sócio-econômica. Os motivos para o desmame precoce vão desde a falta de informação sobre o aleitamento materno até o retorno da mulher ao mercado de trabalho. Com o intuito de resolver estes e outros problemas, os hospitais públicos e alguns privados iniciaram trabalhos de conscientização da gestante, no pré-natal, e criaram os Bancos de Leite Humano (BLH). A qualidade do leite humano cru e processado no BLH está relacionada às condições higiênico-sanitários adotadas desde a coleta até a distribuição. O nível de contaminação microbiana do leite após o processamento térmico (pasteurização $62,5^{\circ} \mathrm{C} / 30$ minutos) garante a morte de possíveis patógenos presentes do leite e assegura a qualidade do produto; porém, não elimina somente patógenos, mas também ocasiona perda no valor biológico e possivelmente mudanças químicas na fração lipídica. Tendo em vista que a qualidade nutricional e imunológica, assim como a segurança do produto, resultam de um conjunto de ações de controle e monitorização, faz-se necessário implantar as boas práticas de processamento e sistema de controle preventivo para identificar e corrigir os pontos falhos na cadeia produtiva e na manipulação.

Palavras chaves: Aleitamento materno, banco de leite humano, qualidade microbiológica. 


\section{ÍNDICE}

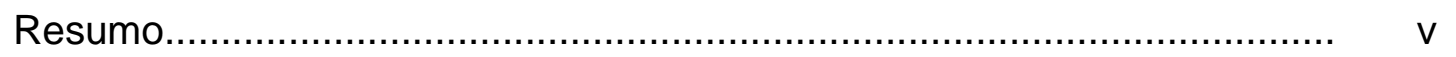

1 - Introdução..................................................................... $1-2$

2 - Objetivos 2

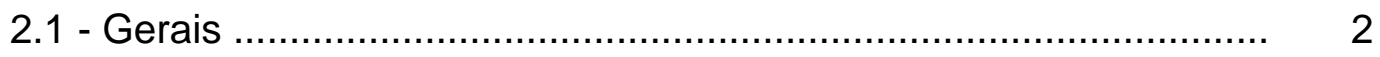

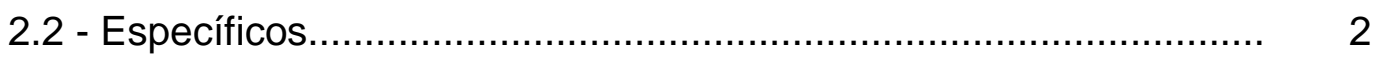

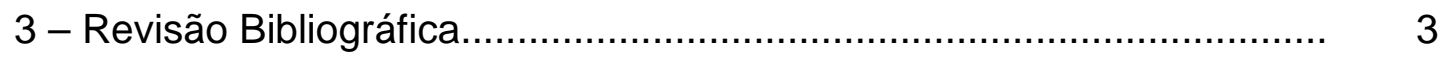

3.1 - Histórico do Aleitamento Materno no Brasil.......................... 3-5

3.2 - Programas Oficiais de Incentivo ao Aleitamento Materno............ 5-9

3.3 - Fatores que Afetam a Continuidade do Aleitamento Materno....... 9-12

3.4-Inocuidade do Leite Materno, Qualidade Nutricional e Imunológica 12-18

3.5 - Garantia da Qualidade e Segurança Alimentar no BLH.............. 18-21

4 - Considerações Finais................................................................... 22-23

5 - Referências......................................................................... $24-29$

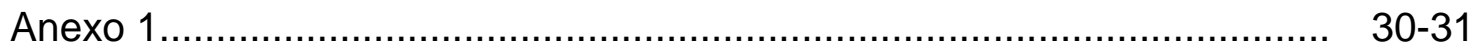

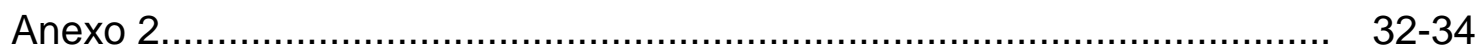

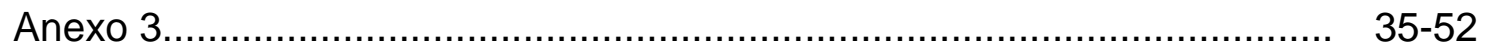




\section{1 - INTRODUÇÃO}

O aleitamento materno é um assunto bastante discutido pelos profissionais da área médica. $\mathrm{O}$ ato de amamentar já passou por etapas de valorização e de desvalorização, e somente século passado, no início da década de 70 , teve início o movimento mundial de retomada do aleitamento materno até os seis meses de idade, no mínimo.

No Brasil, os programas oficiais de incentivo ao aleitamento materno iniciaram-se na década de 80 com o Programa Nacional de Incentivo ao Aleitamento Materno (PNIAM) e a criação dos Bancos de Leite Humano (BLH). A partir de então, seguiram-se outras práticas para mobilização da sociedade que culminaram, em 1986, com o aumento médio do período de amamentação. Pesquisas realizadas na década de 90 demonstraram que há necessidade de campanhas periódicas, envolvendo a mídia, para esclarecer a população e elevar os níveis de amamentação. Estes níveis são prejudicados por fatores como a volta da mulher ao trabalho, desemprego e a falta de informação sobre a prática do aleitamento materno.

Apesar dos esforços para elevar os índices de duração da lactação, o desmame precoce ainda é preocupante, principalmente na população de baixa condição sócio-econômica que, pela falta de saneamento básico, é mais exposta a riscos de doenças parasitárias, infecto-contagiosas e, por conseqüência, acaba comprometendo o estado fisiológico da criança.

A qualidade microbiológica do leite humano ordenhado é mais uma preocupação com a saúde do bebê. Esse alimento é manipulado e processado pelo BLH, que tem por objetivo garantir a inocuidade do produto, conforme estabelecido pelo Instituto Fernandes Figueira (IFF) / Fundação Osvaldo Cruz (FIOCRUZ). Neste sentido, deve-se considerar as condições 
higiênico-sanitárias adotadas desde a coleta, seja no hospital ou em domicílio, até a distribuição pelo lactário. Nos BLHs é prática corrente a pasteurização do leite humano para garantir tal inocuidade. Entretanto, como para outros produtos, tal processo leva a perdas nutricionais e bacteriostáticas.

\section{2 - OBJETIVOS}

\section{1 - GERAIS}

- Fazer um histórico do aleitamento materno no Brasil e dos programas de incentivo ao ato de amamentar.

- Compilar estudos científicos sobre a qualidade microbiológica do Leite Humano, manipulado pelos Bancos de Leite.

\section{2 - ESPECÍFICOS}

- Identificar quais são os fatores externos que influenciam na qualidade microbiológica do leite humano manipulado pelos Bancos de Leite Humano.

- Avaliar o cumprimento das normas padronizadas pelo Instituto Fernandes Figueira / Fundação Oswaldo Cruz para funcionamento dos Bancos de Leite Humano (BRASIL, 2003). 


\section{3 - REVISÃO BIBLIOGRÁFICA}

\section{1 - HISTÓRICO DO ALEITAMENTO MATERNO NO BRASIL}

O aleitamento materno exclusivo até os seis primeiros meses de idade e posterior manutenção da amamentação, com introdução de alimentos, até os dois anos, constituem práticas indispensáveis para a saúde e o desenvolvimento da criança. Este fato é um consenso amplamente conhecido e divulgado pelas instituições de saúde governamentais (Organização Mundial da Saúde (OMS) e Ministério da Saúde (MS)) e nãogovernamentais.

O histórico dos programas de incentivo ao aleitamento materno reforça o hábito da amamentação exclusiva, porém demonstra grandes oscilações nos índices de desmame desde o século XVIII, período em que foram iniciadas as campanhas de esclarecimento à população, veiculadas por profissionais enfermeiros, médicos e educadores, dentre outros. Mesmo que, atualmente, o contexto dos programas seja diferenciado daquele dos séculos XVIII e XIX é interessante destacar que todos têm em comum a visão behaviorista, que visa modificar comportamentos apreendidos culturalmente e impor o ato de amamentar como um dever (JAVORSKI, 1999).

A maternidade da mulher burguesa brasileira passou a ser valorizada somente a partir do século XIX, decorrente da prática adotada no período colonial, quando amas de leite alimentavam os bebês (JAVORSKI, 1999). Era uma prática comum; jornais brasileiros da época oferecerem aluguel ou venda de escravas com filhos pequenos (MARTINS FILHO, 2003).

No século XIX e início do século $X X$ os médicos higienistas, na maioria 
homens, desvalorizavam e desautorizavam o conhecimento feminino na criação dos filhos e interferiam na prática livre do aleitamento, ditando horários rígidos e intervalos de mamadas. Apesar dos esforços na divulgação do aleitamento materno, mesmo que na forma padronizada pelos médicos, e os apelos em discursos sobre o tema, foi inevitável o abandono da amamentação natural iniciado na Europa no final do século XIX, coincidindo com a Revolução Industrial e chegando até o século XX, após a Guerra Mundial (JAVORSKI, 1999).

Com o domínio da tecnologia de beneficiamento do leite de vaca as indústrias de laticínios disponibilizaram para a população um alimento saudável e de qualidade microbiológica; assim, não foi difícil para as indústrias adaptarem este produto às necessidades nutricionais das crianças. Fazia-se necessária, no entanto, criar estratégias de propagandas e divulgação para induzir o consumidor a substituir o leite materno por leite de vaca pasteurizado ou desidratado. Com a fácil aceitação do produto pelos consumidores, e ainda a recomendação médica, a prática de aleitamento artificial colaborou para altas taxas de mortalidade infantil e afetou a qualidade de vida das crianças nos países em desenvolvimento, isso em decorrência do aumento de diarréia e da desnutrição (JAVORSKI, 1999).

Com a produção em escala industrial e o avanço na tecnologia dos equipamentos de refrigeração e laticínios, a divulgação do aleitamento artificial tornou-se uma ocorrência rotineira, pois naquela época pouco se conhecia sobre o papel protetor do leite humano e de seus constituintes imunológicos (MARTINS FILHO, 2003).

$\mathrm{Na}$ década de 70 iniciou-se um movimento mundial que enfatizou a importância da retomada da prática do aleitamento materno exclusivo até os seis meses de idade. No Brasil, esse movimento só foi consolidado com Programa Materno Infantil, em 1974, e o Programa Nacional de Incentivo ao 
Aleitamento Materno, em 1981 (JAVORSKI, 1999).

\section{2 - PROGRAMAS OFICIAIS DE INCENTIVO AO ALEITAMENTO MATERNO}

As atividades de incentivo ao aleitamento materno, no Brasil, apresentavam-se de forma isolada até o início de 1980 e envolviam apenas os profissionais da saúde. Em 1981 criou-se o Programa Nacional de Incentivo ao Aleitamento Materno (PNIAM), no Instituto Nacional de Alimentação e Nutrição (INAN), órgão responsável pelo planejamento de ações de promoção, proteção e apoio ao aleitamento natural, que teve por objetivo reduzir a morbi-mortalidade infantil e melhorar a qualidade de vida das crianças brasileiras (ARAÚJO (2002), citado por ARAÚJO et al.,2003; AUDI et al., 2003).

A preocupação em resgatar a prática do aleitamento materno foi consolidada com programas como o PNIAM (1981), como o Pacto pela Infância no Brasil (1994) e o Hospital Amigo da Criança, que incentivaram hospitais e maternidades a adotarem os "dez passos para o sucesso do aleitamento materno" (PERCEGONI et al., 2002; LAMOUNIER, 1996).

As propostas de maior destaque do programa brasileiro PNIAM, em 1981, foram a abrangência nacional, a mobilização social de todos os segmentos da sociedade e o marketing com campanhas bem elaboradas divulgadas na mídia. Baseado nesses fatores, em 1986, pode-se verificar por meio de uma avaliação que, após 5 anos de campanha, a duração mediana da amamentação aumentou no Estado de São Paulo de 2,9 para 4,2 meses e em Recife de 2,2 para 3,5 meses, conforme menciona REA (2003). Segundo Venâncio \& Monteiro (1998), citado por KITOKO et al. (2000), um estudo de âmbito nacional revelou um aumento na duração 
mediana da amamentação de 2,5 meses, em 1975, para 5,5 meses em 1989. Os estudos da Pesquisa Nacional sobre Demografia e Saúde realizada em 1996 mostram tendência no aumento da amamentação, mas sua prevalência exclusiva em crianças com até 4 meses ficou estimada em 40\%, segundo dados da OMS 1994, citado por KITOKO et al. (2000).

A mobilização social iniciou-se com a campanha na mídia com cobertura de quase cem canais de televisão e seiscentas estações de rádio, além de quatro propagandas na imprensa escrita, com o intuito de atingir os líderes formadores de opinião. Havia também folhetos de loteria esportiva, contas de água, telefone e energia e extratos bancários com o tema "Dê o Seio ao Seu Filho Pelo Menos Durante os Seis Primeiros Meses" (REA, 2003).

Em 1985, o Instituto Fernandes Figueira / Fundação Oswaldo Cruz, iniciou a implantação do Banco de Leite Humano, uma atividade isolada em poucos hospitais do país. Em 1986, a Assembléia Mundial de Saúde votou a resolução que esclarece o artigo 6 do código sobre doações de substitutos de leite materno condenando o uso de substitutos e intitulados como leites de seguimento (REA, 2003).

Pelo menos até 1988 foram consolidadas quatro políticas próamamentação no país. Dentre elas, Norma Brasileira de Comercialização de Alimentos para Lactentes, após meses de negociação com indústrias de alimentos; regulamentação do BLH pelo MS, que estabelece normas de funcionamento e capacitação técnica tendo o IFF como referência nacional e o direito da trabalhadora a quatro meses de licença maternidade e do pai a cinco dias de licença paternidade, incluído na nova Constituição Brasileira (REA, 2003; MARTINS FILHO, 2003). 
Em 1989, a OMS e o United Nations Children's Fund (UNICEF) divulgaram o documento "Declaração Conjunta sobre o Papel dos Serviços de Saúde e Maternidade" em que mencionam ações relativas ao incentivo da amamentação intitulado de "Os dez passos para o sucesso do aleitamento materno". Até aquele momento não existia bibliografia disponível que abordasse o tema e capacitasse os profissionais de saúde. Em 1991 foi lançada a Iniciativa Hospital Amigo da Criança (IHAC), que adotou "Os dez passos para o sucesso da amamentação" (anexo 1) e rejeitou as doações de substitutos do leite materno. Em 1997 a capacitação pessoal foi enfocada como uma atividade determinante para o bom funcionamento dos programas (REA, 2003). Atualmente, existem 232 Hospitais Amigos da Criança, em 24 estados brasileiros, que incentivam a amamentação, como mostra o anexo 2 (BRASIL, 2004a).

Os dados disponíveis sobre a situação do aleitamento materno no Brasil foram divulgados em 1989 pela Pesquisa Nacional sobre Saúde e Nutrição (PNDS). Este estudo verificou que a duração mediana da amamentação foi de 134 dias (crianças amamentadas com e sem complementos), sendo que a amamentação completa (sem adição de alimentos ou água) foi de 72 dias. Para a região do Sudeste a mediana da amamentação completa foi de 82 dias. Em 1996, houve a divulgação do PNDS sobre o aumento da prática da amamentação no País. Para crianças de 0 a 4 meses de idade a freqüência da amamentação elevou-se de 73,5\% para $85,4 \%$ e para crianças de 10 a 14 meses elevou-se de 27,5\% para 37,1\% (CARVALHAES et al., 1998).

Nos anos de 2000 e 2001 houve grandes projetos, como a coleta de leite humano domiciliar realizada em parceria com o Corpo de Bombeiros, chamado de Projeto Bombeiro Amigo, e o Projeto Carteiro Amigo da Amamentação, uma parceria dos profissionais da saúde com os da Empresa de Correio e Telégrafos. 
No ano de 2003, o total de leite humano coletado foi de 16,4 mil litros, dos quais 10,7mil foram coletados pelos bombeiros, que distribuíram aos bancos de leite do Distrito Federal (BRASIL, 2004 b).

Pesquisas realizadas nas capitais brasileiras e no Distrito Federal, em 1999, sobre a Prevalência de Aleitamento Materno, demonstravam a necessidade de serem realizadas periodicamente campanhas, projetos e parcerias com o enfoque na divulgação de informações para a população sobre a importância da amamentação, com o intuito de elevar os índices de aleitamento materno no Brasil. Essas pesquisas evidenciaram que o desmame precoce ainda é um problema de saúde pública, pois o aleitamento exclusivo atinge somente $53,1 \%$ das crianças no primeiro mês de vida, reduzindo drasticamente para 9,7\% a freqüência da amamentação exclusiva no intervalo de 151-180 dias. A duração mediana do aleitamento materno no Brasil, em 1999, foi de 23,4 dias (ARAÚJO et al., 2003).

O relatório de pesquisa de prevalência do aleitamento materno, em 2001, apresentou dados de duração mediana de aleitamento materno inferior a 12 meses. Em todas as capitais nacionais estudadas o aleitamento materno exclusivo foi inferior a 70 dias (ARAÚJO et al., 2003).

Índices alarmantes fornecidos pela Secretaria Estadual de Saúde do Ceará registraram, em 1987, que de 1000 crianças nascidas no estado, 106 morriam antes de completar um ano de idade. Naquele mesmo ano, o governo criou o programa Viva Criança, que incentivou o aleitamento materno, entre outras práticas de saúde (ARAÚJO et al., 2003).

Considerando que os programas implementados até agora conseguiram melhorar gradativamente os índices de amamentação, observa-se a necessidade de continuamente fortalecer as campanhas de 
promoção, proteção e apoio ao aleitamento materno para obter resultados ainda mais expressivos. Neste sentido o projeto do Carteiro Amigo da Amamentação tem por objetivo informar à comunidade a importância e as vantagens da amamentação tanto para a saúde da mãe como para a do filho. $O$ trabalho de orientação das nutrizes e gestantes é realizado com distribuição de folders em domicílio onde residam mulheres com crianças menores de 1 ano. Esses folhetos explicativos foram desenvolvidos pelo Ministério da Saúde e apresentam os dez passos para se obter sucesso no aleitamento materno. A presença do carteiro facilita a aceitação por parte da comunidade, tornando-os potenciais multiplicadores de informações (ARAÚJO et al., 2003).

O Projeto Carteiro Amigo da Criança foi desenvolvido no Ceará, em 1996, com incentivo e participação de algumas empresas, entidades e organizações não-governamentais que se mobilizaram juntamente com o governo para informar e incentivar as mães a amamentarem seus filhos. Para sua implementação e ampla atuação, realizou-se, no primeiro semestre de 1996, um treinamento com 585 carteiros que, posteriormente, distribuíram aproximadamente 100.000 folders; este projeto foi estendido a 9 estados da região Nordeste. No ano seguinte chegou aos estados da região Norte e Centro-Oeste. Em 2001 alcançou os estados da região Sul e Sudeste; neste ano foram distribuídos mais de 1 milhão de folders em 248 municípios brasileiros. O reconhecimento veio em 1997, com a divulgação do projeto pela British Broadcasting Corporation (BBC), em 2000, com o prêmio "Top Social" da Associação Brasileira dos Dirigentes de Vendas e Marketing do Brasil e, em 2001, com o prêmio "Hélio Beltrão" no VI Concurso de Inovações na Gestão Pública Federal (ARAÚJO et al., 2003; BRASIL, 2004 a).

\section{3 - FATORES QUE AFETAM A CONTINUIDADE DO ALEITAMENTO MATERNO}


A prática do aleitamento materno é interrompida precocemente por uma série de fatores que estão relacionados ao contexto sócio-cultural da mulher. Um deles é o retorno da mulher ao mercado de trabalho com atividade fora do lar, condição agravada por grandes distâncias a serem percorridas do trabalho à residência, utilizando o transporte ineficiente das grandes cidades. Os altos índices de desemprego obrigam as mães, principalmente as jovens de baixa renda, a participarem financeiramente no orçamento da casa; contribuindo gradativamente para o abandono da amamentação (OLIVEIRA \& SILVA, 2003).

Segundo Oliveira \& Silva (2003), pesquisas demonstram que as empresas estão respeitando o direito à amamentação, conforme disposto na Consolidação das Leis Trabalhistas (Brasil, CLT (1943): título III, capítulo III, seção V, artigo 396) dispensando as mães para a prática do aleitamento no local de trabalho, oferecendo um local apropriado para a guarda dos lactentes, seja berçário ou creche. Caso não haja local apropriado, o bebê fica em uma creche conveniada bem próxima ao trabalho da mãe.

Além disso a carência de informação sobre o aleitamento materno, observado em justificativas do tipo: "o bebê chora muito" ou "o leite é fraco, não sustenta"; a falta de preparação das mães durante o pré-natal, identificado pela insegurança e ansiedade, a falta de técnica do aleitamento materno também são fatores relevantes que prejudicam a amamentação (AUDI et al., 2003; PERCEGONI et al., 2002; JAVORSKI, 1999).

Estudo realizado por Lima \& Osório (2003) na região do Nordeste brasileiro, em 1996, revelou alguns fatores que influenciam a duração do aleitamento materno. A variável demográfica mostra que a duração mediana do aleitamento materno nas áreas rurais é significativamente maior que na área urbana, com $60,8 \%$ e 50,7\%, respectivamente, em crianças amamentadas até 6 meses de idade. Isto se deve à rotina das mães 
residentes na área rural que, majoritariamente, não trabalha fora do lar. A idade materna apresentou associação significativa com a duração do aleitamento, pois as mães adultas são mais experientes e possuem maturidade para cuidar da alimentação dos seus filhos. Nesta pesquisa, considerou-se também que a utilização da mamadeira, no início da amamentação, parece retardar a lactação por confundir o reflexo da sucção do recém-nascido não havendo o estímulo adequado da suç̧ão, o que desfavorece a produção de leite. Para AUDI et al. (2003), a relação entre o uso da chupeta e a interrupção do aleitamento materno exclusivo é controversa.

Carvalhaes et al. (1998) verificaram a introdução precoce de líquidos e complementos lácteos em crianças com 1 mês de idade; assim como KITOKO et al. (2000) que afirmaram que a amamentação exclusiva é interrompida muito cedo com a introdução precoce de água e chás. Para Audi et al. (2003), o uso de infusão, com propriedade calmante ou laxativa, é uma prática inadequada e desnecessária do ponto de vista biológico, considerando os dias quentes e secos. Esta prática, além de reduzir o consumo total de leite materno, pode causar o desmame precoce. Destacase ainda que a falta de informação e de apoio dos profissionais da área de saúde após o parto foram outros fatores importantes detectados nesta pesquisa, que influenciaram a prática da amamentação (LIMA \& OSÓRIO, 2003; PERCEGONI et al., 2002). Lima \& Osório (2003) também verificaram que crianças entre 0 a 3 meses de idade tiveram a oferta de água e consumiram leite artificial em suas dietas, alcançando valores de $58,9 \%$ e $54,8 \%$, respectivamente, da população estudada.

Pesquisa realizada pela Faculdade de Saúde Pública da Universidade de São Paulo (USP) revelou que das 34.435 crianças estudadas, de 111 municípios do estado, apenas $13,9 \%$ dos bebês até seis meses foram amamentados exclusivamente com leite materno. $O$ estudo também verificou que quanto maior o número de ações de incentivo à amamentação 
implantada nos municípios, maiores as chances de amamentação exclusiva, pois nos municípios com cinco ações de incentivo, 22,4\% das crianças foram amamentadas até seis meses e municípios com quatro e três ações possuíam índices de $21,5 \%$ e 12,4\%, respectivamente. Nos municípios sem programas de incentivo ao aleitamento o índice foi de 10,2\% (BRASIL, 2004 d).

Diagnosticar o nível de conhecimento da mãe sobre o aleitamento materno, em cada região, contribui para um mapeamento e direcionamento de atenção à saúde naquela população, orientando os indivíduos quanto às práticas mais adequadas de amamentação e alimentação dos jovens bebês (PERCEGONI et al., 2002). O diagnóstico rápido da situação de amamentação e a padronização do método de coleta de dados são importantes meios para definir e redirecionar as políticas na área de saúde, específicas à nutrição materno-infantil (KITOKO et al., 2000).

\section{4 - INOCUIDADE DO LEITE MATERNO, QUALIDADE NUTRICIONAL E IMUNOLÓGICA}

A qualidade microbiológica do leite humano, manipulado e processado pelo BLH, está diretamente relacionada aos procedimentos técnicos e higiênico-sanitários adotados, desde a coleta até a distribuição (ALMEIDA et al., 1989). A presença de elevado nível de contaminação do leite humano cru pode acarretar a redução do valor imunológico e conseqüente redução na proteção ao organismo do lactente (KAMIYA \& RAMOS, 2003). Segundo NOVAK et al. (2001a), o leite humano ordenhado de doadoras saudáveis é, microbiologicamente, inócuo. Assim, a presença de patógenos está associada à contaminação externa e reflete condições higiênico-sanitárias insatisfatórias. 
O leite humano não possui uma barreira física que impeça a contaminação microbiológica; desta forma, a microbiota pode ser de origem primária, que corresponde aos microrganismos que passam diretamente da corrente sangüínea para o leite, ou de origem secundária, que são provenientes da pele e penetram através do mamilo habitando a região mais externa dos ductos lactíferos. Os contaminantes secundários são aqueles provenientes do meio externo ou da manipulação em condições higiênicosanitárias inadequadas (KAMIYA \& RAMOS, 2003; BJÖRKSTÉN et al., 1980). A grande variedade de bactérias encontrados no leite também pode ser explicada pelos diferentes métodos de coleta (BJÖRKSTÉN et al., 1980).

Os recém-nascidos são continuamente expostos a novos microrganismos veiculados pelos alimentos, inclusive pelo leite materno, por possuir uma microbiota contaminante variável entre $10^{2}-10^{9}$ microrganismos $/ \mathrm{ml}$ originada do mamilo, dos ductos lactíferos, da pele circundante e das mãos maternas. $O$ isolamento, a identificação e a caracterização das espécies de microrganismos presentes nos alimentos têm sido objeto de estudo constante entre os pesquisadores, porém é um trabalho minucioso e demorado (BORBA et al., 2003).

O controle microbiológico adotado pelos bancos de leite humano possui a praticidade de uma análise de rotina, ou seja, faz uso de métodos simples e de baixo custo. Normalmente são utilizados como indicadores de contaminação de origem fecal, direta ou indiretamente, os coliformes totais, coliformes fecais e Escherichia coli (KAMIYA \& RAMOS, 2003).

O grupo de coliformes totais inclui bactérias gram-negativas não esporuladas, fermentadoras de lactose, com produção de ácido e de gás na faixa de temperatura que varia entre $32^{\circ} \mathrm{C}$ e $37^{\circ} \mathrm{C}$. A ocorrência deste grupo indica a falta ou deficiência de um programa de boas práticas de manipulação, além de ser um alerta para a presença de microrganismos 
patogênicos (NOVAK et al., 2002).

Os coliformes fecais são capazes de fermentar a lactose com produção de ácido e gás na temperatura de $44^{\circ} \mathrm{C}$; seu habitat natural é o trato intestinal dos animais homeotérmicos. Estes são indicadores de contaminação de origem fecal que indicam com maior certeza a presença de outros microrganismos que acompanham a $E$. coli. Dentre os microrganismos isolados, a partir dos testes de coliformes totais, a E. coli é encontrada com maior freqüência, sendo utilizada como indicador para possível presença de patógenos entéricos em alimentos, principalmente em leite humano (NOVAK et al., 2002).

A presença de alguns microrganismos tem fundamental importância para a saúde do recém-nascido. Por exemplo, o $S$. aureus enterotoxigênico produz toxinas resistentes à pasteurização, podendo acarretar sérios problemas como diarréia, náusea, vômito, febre, calafrio, prostração (BANWART, 1979), inclusive quando a doadora não é a mãe do receptor.

Assim, os cuidados com a saúde da lactante, a assepsia durante todo o período de lactação, o atendimento às normas estabelecidas pela Rede Nacional de Bancos de Leite Humano/FIOCRUZ (anexo 3) são essenciais para a obtenção de um produto que atenda às necessidades da criança sem qualquer tipo de risco (BRASIL, 2003). O mesmo é válido para o leite coletado, processado ou não, e armazenado sob refrigeração ou congelamento. Cabe ressaltar que as bactérias lácticas são organismos probióticos importantes com efeitos benéficos no sistema gastrointestinal (NOVAK et al., 2001b).

O Brasil, assim com outros países, adotou o processo lento de pasteurização para garantir a inocuidade e o controle microbiológico do leite 
humano ordenhado. O tratamento térmico torna-se necessário porque não é possível assegurar a total qualidade do produto, dada a variedade das condições culturais, educacionais, sócio-econômicas da população. Para tanto, o leite é aquecido a $62,5^{\circ} \mathrm{C}$ por 30 minutos; este binômio de tempo/temperatura garante a morte de possíveis patógenos presentes do leite, assim como a inativação do vírus HIV (PASCHOA, 1997).

Trabalho realizado no Hospital Universitário da Universidade Federal do Mato Grosso do Sul (UFMS) verificou que o leite obtido no próprio BLH é microbiologicamente melhor que o leite obtido de coleta externa ou em domicílio, pois todas as amostras coletadas internamente foram negativas para coliformes totais, enquanto que $59,57 \%$ das amostras de leite cru, obtidas externamente, foram positivas para o mesmo teste. Este trabalho confirma a eficiência da pasteurização na destruição dos microrganismos, pois obteve resultados negativos para coliformes totais em todas as amostras coletadas externamente, após o processamento térmico. (KAMIYA \& RAMOS, 2003).

Outro estudo de avaliação microbiológica do leite humano, realizado no BLH de Goiânia, mostrou que em 61 amostras analisadas, 100\% apresentaram bactérias mesófilas variando de 10 a $10^{8} \mathrm{UFC} / \mathrm{ml}$, assim como as psicrotróficas com variação entre 10 e $10^{7} \mathrm{UFC} / \mathrm{ml}$. As termodúricaspsicrotróficas foram detectadas em apenas 1 amostra e Staphylococcus coagulase positiva foi identificado em 13 das 61 amostras, mas apenas 11 com significância $\left(10^{2}\right.$ a $\left.10^{4} \mathrm{UFC} / \mathrm{ml}\right)$. Os coliformes fecais e totais foram isolados em 54 amostras, com contagens entre 10 e $10^{3} \mathrm{NMP} / \mathrm{ml}$, porém Escherichia coli não foi encontrada. Este trabalho permitiu constatar uma elevada contaminação do leite humano cru e a eficácia do processo de pasteurização, uma vez que foi efetiva a eliminação das bactérias termodúricas-psicrotróficas (CARVALHO, 2002). Outras pesquisas foram conduzidas com o objetivo de identificar os tipos de microrganismos no leite humano recém ordenhado; os resultados apontam para a presença de 
Escherichia coli, Staphylococcus aureus, Klebsiella pneumoniae, Enterobacter sakazakii, Serratia sp., Proteus sp., Salmonella typhimurium, bactérias lácticas e outros (LIRA, 2002; NOVAK et al., 2001 a e b; MOULIN et al., 1998; ALMEIDA et al., 1989; BJÖRKSTÉN et al., 1980).

Convém ressaltar que o processo de pasteurização não elimina apenas os patógenos. Microrganismos considerados da flora normal, assim como fatores de proteção presentes no leite humano são também destruídos em maior ou menor intensidade, dependendo da sua termorresistência. Dentre estes fatores citam-se as imunoglobulinas $\lg \mathrm{A}$, IgM, IgG (são anticorpos que possuem a função de combater antígenos estranhos ao corpo humano e se diferem pela seqüência de aminoácidos na cadeia constante (SHARON, J. 1998)), lisozimas, lactoferrina, fator bífido, macrófagos, linfócitos, granulócitos, neutrófilos, células epiteliais, que constituem uma barreira bioquímica à ação microbiana (KAMIYA \& RAMOS, 2003).

A concentração desses fatores é maior no colostro do que no leite maduro, porém estes sofrem o efeito da pasteurização de modo diferenciado: há perda de 30\% de $\operatorname{lgA}, 1 / 3$ da $\lg$, 2/3 de lactoferrina e destruição da $\operatorname{lgM}, 100 \%$ dos macrófagos, neutrófilos, linfócitos e 23\% de lisozima (PASCHOA, 1997; BJÖRKSTÉN et al., 1980). Deve-se considerar ainda que o tempo necessário para atingir a temperatura de processamento, o tempo de resfriamento, o volume de leite processado e o conteúdo protéico total também influenciam tais resultados (BJÖRKSTÉN et al., 1980).

Em função da destruição total ou parcial dos fatores acima mencionados, o leite pasteurizado pode apresentar uma redução no seu valor nutricional. Para tanto, faz-se necessário seguir rigorosamente os procedimentos para o processo de pasteurização, que devem imediatamente ser seqüênciado pelas operações de refrigeração ou congelamento para evitar o ataque microbiano que, neste caso, não teria mais a barreira 
bioquímica original como freio e se desenvolveria às custas dos nutrientes do leite, reduzindo seu valor biológico. Deve-se considerar também que a pasteurização não assegura a completa descontaminação do leite, mas é um compromisso entre o risco aceitável e a manutenção parcial das suas propriedades bacteriostáticas (NOVAK et al., 2001a; ALMEIDA et al., 1989; BJÖRKSTÉN et al., 1980).

Além das perdas supracitadas ocasionadas pelo processo térmico, um estudo realizado no BLH do Hospital Universitário da UFMS analisou o teor lipídico do leite humano e observou que as quantidades médias de lipídios nas amostras de leite humano cru e pasteurizado foram de 3,26\% e 2,41\%, respectivamente. Este estudo contabilizou perda de lipídios em torno de $26 \%$ durante o processamento térmico, provavelmente, isto deve a mudança na fração lipídica decorrente da hidrólise térmica e conseqüente oxidação deste nutriente, reduzindo assim sua concentração. Em relação ao valor calórico total das amostras, a pesquisa verificou que a média para o leite cru e pasteurizado foi de $647,8 \mathrm{kcal} / /$ e $562,91 \mathrm{kcal} / /$ respectivamente, totalizando perda de aproximadamente 13\%. Resultados como estes também foram encontrados no trabalho de Lopes, et al. (1992) e Ferreira et al. (1998), citados por KAMIYA \& RAMOS, 2003.

Trabalho conduzido por Borgo et al. (2003) para avaliar os procedimentos operacionais nos BLH do Distrito Federal verificou que, durante o período de escassez de leite humano, alguns bancos repasteurizam o leite que apresentou segunda análise positiva para coliformes totais e o fornecem a não recém-nascidos. Convém ressaltar que esta prática implica em maior perda nutricional e bacteriostática do produto, e não é citada nas normas padronizadas pelo Instituto Fernandes Figueira / Fundação Oswaldo Cruz para funcionamento dos Bancos de Leite Humano.

Em outros países, como a Suécia e a Finlândia, a pasteurização não é realizada; entretanto, todo o leite doado é previamente analisado para assegurar sua qualidade o que, para países pobres e em desenvolvimento, 
seria mais oneroso (BJÖRKSTÉN et al., 1980). Por isso a opção pela pasteurização, processo mais simples e de custo mais acessível.

Para realizar o controle estático da qualidade microbiológica não possível adotar nenhum plano de amostragem e nem utilizar o conceito de lote nos Bancos de Leite, pois cada frasco foi obtido de uma doadora em condições higiênico-sanitárias específicas, obtendo uma carga microbiana secundária bem diversificada, até mesmo entre os frascos fornecidos pela mesma doadora. Desta forma, o controle da qualidade é realizado individualmente em cada frasco após a pasteurização; isso demanda tempo, mão-de-obra e grande quantidade de material de análise (NOVAK et al., 2002).

Devido ao grande número de amostras e à velocidade de reciclagem do estoque de leite humano, é praticamente impossível examinar todas as amostras de leite pasteurizado à procura de microrganismos patogênicos; por isso, a avaliação higiênico-sanitária dos produtos fornecidos pelos BLH fica restrita apenas aos testes de coliforme totais, determinando a necessidade de estudar novos métodos de análise que permitam realizar uma maior amostragem com a mesma segurança dos testes tradicionais e custos mais reduzidos (NOVAK et al., 2002). Para Panichi et al. (2002), uma forma indireta de mensuração do padrão de qualidade da cadeia produtiva é a monitorização constante dos valores de acidez Dornic do leite humano ordenhado, sendo também um método simples e pouco oneroso.

\section{5 - GARANTIA DA QUALIDADE E SEGURANÇA ALIMENTAR NO BLH}

A segurança alimentar e a qualidade dos produtos e serviços ofertados à população em geral, ou a grupos específicos, são assuntos delicados e que devem ser avaliados rotineiramente, pois falhas no processamento ou na conservação do alimento podem desencadear patologias provenientes de 
infecções alimentares ou agravar o estado nutricional ou fisiológico de um indivíduo já debilitado.

Os estudos de segurança e qualidade do produto final também se aplicam a hospitais e à rede de banco de leite humano que atendem uma clientela especial, por se tratar de gestantes, nutrizes, bebês prematuros, recém-nascidos de baixo peso, bebês com dificuldade de sucção durante a amamentação, crianças com quadro de infecção ou portadores de deficiências imunológicas, alergia a proteínas heterólogas e, por fim, lactentes sadios (BRASIL, 1998b e c, citado por CARDOSO et al., 2000).

Nos últimos 15 anos, houve um crescimento no número de BLH devido aos programas de incentivo e divulgação da importância do aleitamento materno; com esse avanço, fez-se necessário organizar e normatizar o funcionamento destes serviços, promovendo a garantia da qualidade (CARDOSO et al., 2000). Atualmente, a Rede Nacional de Bancos de Leite Humano tem 151 unidades instaladas nos hospitais e espalhadas em 25 estados brasileiros beneficiando milhares de crianças prematuras e de baixo peso. Cerca de 100mil litros de leite são coletados por estes bancos (BRASIL, 2004c).

Mesmo que as normas técnicas de funcionamento dos BHL já tenham sido definidas pelos órgãos responsáveis, é interessante comentar que muitos hospitais seguem regras individualizadas para atender suas necessidades. Isso ocorre, principalmente, devido à escassez de recursos para as unidades públicas. É importante ressaltar que a privação de recursos atinge diretamente a qualidade do produto, pois torna-se mais difícil o controle das etapas do processo caso não haja locais adequados de armazenamento ou, ainda, equipamentos adequados para pasteurização e resfriamento do leite humano (CARDOSO et al., 2000).

Estudo realizado por Cardoso et al. (2000) teve por objetivo diagnosticar o sistema de gestão de qualidade da rede de bancos de leite 
humano do Brasil e adotou como metodologia a aplicação de um questionário com perguntas direcionadas à segurança do beneficiamento do leite humano.

Os resultados daquele trabalho mostraram que na etapa de seleção e orientação das doadoras apenas $58,4 \%$ dos consultados realizavam fielmente a seleção, enquanto $32,9 \%$ reportaram pequenas falhas e os $8,7 \%$ restantes informaram falhas maiores ou não souberam informar. Quanto ao transporte do leite, $49 \%$ dos representantes apontaram falhas na cadeia de frio, com o recebimento do produto fora das condições especificadas. $\mathrm{Na}$ etapa da inspeção no recebimento dos produtos, $74 \%$ informaram que utilizavam as técnicas recomendadas para inspeção visual do produto in natura, porém $14 \%$ disseram que as aplicavam com pequenas falhas; $4,7 \%$ as aplicavam pouco e o restante não as aplicavam ou não souberam informar.

Com relação ao tratamento térmico, verificou-se que $85 \%$ dos consultados faziam o estudo preliminar para o estabelecimento das curvas de aquecimento e definição do binômio tempo/temperatura para diferentes tipos de embalagem e volume de leite, porém apenas $75,3 \%$ faziam o controle de variação de temperatura de processamento. É importante comentar que a pasteurização é a única etapa de beneficiamento do leite que elimina o risco à saúde, sendo fundamental que seja monitorada pois é um ponto crítico de controle. Esse trabalho verificou as atividades de controle de qualidade e evidenciou que $66,4 \%$ dos participantes faziam o registro de controle dinâmico e apenas $29 \%$ seguiam o modelo APPCC (Análise de Perigos e Pontos Críticos de Controle) de registro (CARDOSO et al., 2000).

Cabe mencionar que, aliado ao não cumprimento das normas estabelecidas pelo IFF/FIOCRUZ, existem também falhas nos 
planejamentos dos Bancos de Leite, pois a localização e o projeto de arquitetura (como lay-out, fluxo unidirecional, disposição de portas e janelas, tipo de piso e parede, iluminação, ventilação, localização de equipamento) são determinantes para evitar a contaminação cruzada, contribuindo favoravelmente na qualidade do produto final (PACHOA, 1997).

Segundo Cardoso et al. (2000) e Popper et al. (2001) o modelo APPCC é o mais adequado para assegurar a qualidade do produto. A visão de controle de qualidade do produto final deve ser deslocada para as várias etapas de beneficiamento com monitoramento rigoroso e exclusão antecipada de amostras inadequadas; não sendo necessário o controle microbiológico final do leite humano pasteurizado.

Atualmente, está em início de implantação o Programa Nacional de Qualidade em Bancos de Leite Humano, que é um projeto de ação integrada elaborado pelo Instituto Fernandes Figueira - FIOCRUZ em conjunto com a Área da Saúde da Criança da Secretaria de Políticas de Saúde, com o objetivo de promover condições que permitam certificar a qualidade dos produtos e serviços sob a responsabilidade dos Bancos de Leite Humano em todo o País. O conteúdo técnico do programa, sua elaboração e operacionalização é de responsabilidade do Centro de Referência Nacional para Bancos de Leite Humano do IFF/FIOCRUZ, que conta com a participação do Programa Nacional de Controle de Qualidade da Sociedade Brasileira de Análises Clínicas para o fornecimento do material necessário à realização dos testes de proficiência (BRASIL, 2004 e). 


\section{4 - CONSIDERAÇÕES FINAIS}

Os Bancos de leite são considerados estabelecimentos de saúde organizados em rede, com programas e metas específicas, cujo objetivo é garantir a qualidade microbiológica, nutricional e imunológica do leite materno. No entanto, foi possível notar, baseado neste levantamento bibliográfico, que há muito a se trabalhar nos hospitais públicos e privados que disponibilizam este tipo de serviço, pois existem pontos falhos tanto na cadeia produtiva e manipulação, quanto no sistema de informação que abrange desde o profissional da área da saúde até a doadora.

Por se tratar de um alimento destinado a uma população que necessita de cuidados especiais, é de extrema importância monitorar toda a cadeia produtiva e não se ater somente ao processamento térmico, como ocorre na maioria dos estudos relatados. Apesar da pasteurização ser o único processo de eliminação ou de redução da carga microbiana utilizado pelo $\mathrm{BLH}$, isto não nos assegura totalmente quanto à qualidade do produto, pois não são conhecidas as verdadeiras condições higiênico-sanitárias durante a manipulação, podendo correr o risco de distribuir um alimento com presença de patógenos.

Os estudos que foram relatados mostraram que é preciso revisar as rotinas e os procedimentos adotados pelos bancos de leite, além de orientar e treinar periodicamente os profissionais da área da saúde para melhor atender às mães e manipular o leite humano ordenhado cru e pasteurizado. Tendo em vista que a qualidade e a segurança do produto resultam de um conjunto de ações de controle, é preciso tornar rotineira a verificação e o registro de cada uma dessas etapas, pois estas informações são determinantes na avaliação da eficiência do sistema de produção e na 
qualidade final do produto.

Cabe ressaltar, ainda, a importância da elaboração do Manual de Boas Práticas de Manipulação para obter um sistema organizado de produção respeitando a particularidade de cada banco de leite e transpondo as limitações de funcionamento. O manual deve ser utilizado para efetivar a implantação das boas práticas de processamento e do sistema de controle preventivo, ambos necessários para alcançar a garantia de qualidade e a segurança do leite humano manipulado. Inicialmente deve-se definir o macroprocesso de forma detalhada, identificar com clareza todas as etapas e eleger requisitos e atributos para cada uma delas, assim estaremos definindo os procedimentos operacionais padrão, fornecendo informações importantes para a elaboração do manual. A implantação do sistema de Análise de Perigos e Pontos Críticos de Controle (APPCC) deve ser 0 próximo passo para alcançar a qualidade e segurança do alimento, mas este só será eficiente se fizer o registro dos dados de controle de qualidade.

A rede de bancos de leite humano está providenciando a implementação do Programa Nacional de Qualidade em Bancos de Leite Humano, com o principal objetivo de promover condições que permitam a certificação da qualidade dos produtos e serviços sob a responsabilidade dos Bancos de Leite Humano em todo o País. 


\section{REFERÊNCIAS}

ALMEIDA, J. A. G.; NOVAK, F. R.; ALMEIDA, C. H. G.; SERVA, V. B. Avaliação parcial da flora microbiana do leite humano ordenhado no IMIP. Revista do IMIP, vol. 3 (1): 13-16, jun-1989.

ARAÚJO, M. F. M.; FIACO, A. D.; WENER, E. H., SCHMITZ, B. A. S. Incentivo ao aleitamento materno no Brasil: evolução do Projeto Carteiro Amigo da Amamentação de 1996 a 2002. Revista Brasileira Saúde Materno Infantil, Recife, vol. 3(2): 195-204, abr- jun, 2003.

AUDI, C. A. F.; CORREAA, A. M. S.; LATORRE, M. R. D. O. Alimentos complementares e fatores associados ao aleitamento materno e ao aleitamento materno exclusivo em lactentes até 12 meses de vida em Itapira, São Paulo, 1999. Revista Brasileira de Saúde Materno Infantil, Recife, vol. 3 (1): 85-93 jan.-mar., 2003.

BANWART, G. J. Basic Food Microbioloby. AVI, Westport, 1979. 781p.

BJÖRKSTÉN, B.; BURMAN, L. G.; CHÂTEAU, P.; FREDRIKZON, B.; GOTHEFORS, L.; HERNELL, O. Collecting and banking human milk: to heat or not to heat? Bristish Medical Journal, vol. 281 (20): 765-769, sep. 1980.

BORBA, L. M.; CASTRO, L. C. V.; FRANCESCHINI, S. C. C.; FERREIRA, C. L. L. F. Composição do leite humano e microbiota predominantemente bífida do lactente em aleitamento materno exclusivo. Nutrire: Revista Sociedade Brasileira de Alimentação e Nutrição = Journal Brazilian Society Food 
Nutrition, São Paulo, SP. vol. 25, p. 135-151, jun. 2003.

BORGO, L. A.; RAMOS, K. L.; ALMEIDA, S. G.; SEIDE, L. O.; OLIVEIRA, L. A.; CARDOSO, L.; ARAÚJO, W. M. C. Avaliação do funcionamento e identificação de pontos críticos de controle em Bancos de Leite Humano no Distrito Federal. Submetido à publicação em 2003.

BRASIL. Fundação Oswaldo Cruz. Manual técnico. Disponível em <http://www.redeblh.fiocruz.br.> Acesso em: 23 nov. 2003.

BRASIL. Ministério da Saúde. Semana Mundial de Aleitamento Materno. Disponível em $<$ http://portalweb01.saude.gov.br/saude/visualizar texto.cfm?idtxt=13534.> Acesso em: 28 fev. 2004 a.

BRASIL. Ministério da Saúde. Ministério da Saúde vai estimular amamentação com ajuda dos bombeiros. Disponível em $<$ http://portalweb01.saude.gov.br/saude/buscar.cfm?inicio=11. $>$ Acesso em: 28 fev. 2004 b.

BRASIL. Ministério da Saúde. Saúde da criança no Brasil - ações estratégicas. Disponível em $<$ http://portalweb01.saude.gov.br/saude/buscar.cfm?inicio=26. $>$ Acesso em: 28 fev. 2004 c.

BRASIL. Ministério da Saúde. Pesquisa da Faculdade de Saúde Pública mostra que adesão ao aleitamento até seis meses é maior onde há ações de incentivo (Folha de São Paulo - 20/08/2003). Disponível em

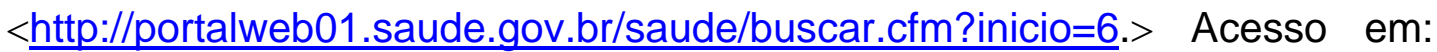


28 fev. 2004 d.

BRASIL. Fundação Oswaldo Cruz. Programa Nacional de Qualidade em Bancos de Leite Humano. Disponível em <http://www.redeblh.fiocruz.br. $>$ Acesso em: 28 fev. 2004 e.

CARDOSO, R. C. V.; CHAVES, J. B. P.; BRANDÃO, S. C. C. Bancos de leite humano e a segurança no beneficiamento de produtos. Higiene Alimentar, vol. 14 n 68/69: 51-57, jan-fev. 2000.

CARVAlHAES, M. A. B. L.; PARADA, C. M. G. L.; MANOEL, C. M.; VENÂNCIO, S. Y. Diagnóstico da situação do aleitamento materno em área urbana do Sudeste do Brasil: utilização de metodologia simplificada. Revista Saúde Pública, vol. 32 (5): 430-436, 1998.

CARVALHO, O. C. Avaliação microbiológica de leite humano coletado em Banco de Leite na Cidade de Goiânia, GO. In; III Congresso Brasileiro de Banco Leite Humano, 2002, Petrópolis. Anais: Pesquisa e Desenvolvimento Tecnológico em Banco Leite Humano. Petrópolis; Rede BLH, 2002. Disponível em :< http://www2.fiocruz.br/bancodedados/redeblh/trabalhos cientificos.pdf > Acesso em; 20 jan. 2004.

JAVORSKI, M. Os programas nacionais de incentivo ao aleitamento materno: uma análise crítica. Revista Pediatria Moderna, vol. $35 n^{\circ}$ 1/2: janfev, 1999.

KAMIYA, E. \& RAMOS, M. I. L. Avaliação microbiológica e calórica do leite humano coletado e distribuído no banco de leite humano do Hospital 
Universitário/NHU/UFMS. Higiene Alimentar, vol. 17(109): 64-68, jun. 2003.

KITOKO, P. M.; RÉA, M. F.; VENANCIO, S. I.; VASCONCELOS, A. C. C. P.; SANTOS, E. K. A.; MONTEIRO, C. A. Situação do aleitamento materno em duas capitais brasileiras: uma análise comparada. Caderno de Saúde Pública, Rio de Janeiro, vol. 16(4): 1111-1119, out-dez, 2000.

LAMOUNIER, J. A. Promoção e incentivo ao aleitamento materno: Iniciativa Hospital Amigo da Criança. Jornal de Pediatria, vol. 72, $\mathrm{n}^{\circ}$ 6: 363-367, 1996.

LIMA, T. M.; OSÓRIO, M. M. Perfil e fatores associados ao aleitamento materno em crianças menores de 25 meses da Região Nordeste do Brasil. Revista Brasileira Saúde Materno Infantil, Recife, vol. 3(3): 305-314, jul/ set., 2003.

LIRA, B. F. Qualidade da fração lipídica do leite humano ordenhado e processado. [Tese] Recife: Universidade de Pernambuco; 2002, 69p.

MARTINS FILHO, J. Evolução do Aleitamento Materno no Brasil. In: RÊGO, J. D. Aleitamento Materno. Editora Atheneu. Disponível em: <www.epub.org.br/nutriweb/n0302/livromartinsfilho.htm>. Acesso em 2 dez.2003.

MOULIN, Z. S.; LAMOUNIER, J. A.; VIEIRA, M. B. C. M.; BAÊTA, M.; SILVA, M. A. D.; ARAÚJO, R. S. S. Contaminação bacteriana do leite humano coletado por expressão manual e estocado à temperatura ambiente. Jornal de Pediatria, vol. 74(5): 376-382, 1998. 
NOVAK, R. F.; ALMEIDA, J. A. G.; ASENSI, M. D.; MORAES, B. A.; RODRIGUES, D. P. Resistência antimicrobiana de coliformes isolados de leite humano ordenhado. Caderno de Saúde Pública, Rio de Janeiro, vol. 17(3): 713-717, mai-jun, 2001a.

NOVAK, F. R.; ALMEIDA, J. A. G.; VIEIRA, G. O.; BORBA, L. M. Colostro humano: fonte natural de probióticos? Jornal de Pediatria, vol. 77 (4): 265$270,2001 b$.

NOVAK, F. R.; ALMEIDA, J. A. G. Teste alternativo para detecção de coliformes em leite humano. Jornal de Pediatria, vol. 78 (3): 193-196, 2002.

OLIVEIRA, R. L. \& SILVA, A N. Aspectos legais do aleitamento materno: cumprimento da lei por hospitais de médio e de grande porte de Maceió. Revista Brasileira de Saúde Materno Infantil, Recife, vol 3(1): 43-48, janmar. 2003.

PANICHI, M. N.; PARIZOTO, G. M.; STANCARI, R. C. A.; DIAS Jr., F. L.; ANDRADE, C. B.; ASSIS, T.C.; BARRETINI, G. A. Avaliação da consistência longitudinal de valores da acidez Dornic no leite humano ordenhado no Banco de leite humano de Bauru, SP. In; III Congresso Brasileiro de Banco Leite Humano, 2002, Petrópolis. Anais: Pesquisa e Desenvolvimento Tecnológico em Banco Leite Humano. Petrópolis; Rede BLH, $2002 . \quad$ Disponível em: <http://www2.fiocruz.br/bancodedados/redeblh/trabalhos cientificos.pdf> Acesso em; 20 jan. 2004.

PASCHOA, M. F. Pasteurização do leite materno: vantagens e desvantagens. Higiene Alimentar, vol. 11 (50):14-19, jul-ago, 1997. 
PASCHOA, M. F. Banco de leite humano: fluxograma e "lay-out". Higiene Alimentar, vol. 11 (49):18-22, maio-jun, 1997.

POPPER, I. O. P.; OLIVEIRA, M. M. B.; VANNUCHI, M. T. O.; BORGES; J. Q.; SILVA, M. P.; NISHIKAWA, L. Y.; LIMA, C. M. A. Produção de leite humano ordenhado "zero defeitos" : uma proposta. Higiene Alimentar, vol. 15 (81): 44-50, mai, 2001.

PERCEGONI, N.; ARAÚJO, R. M. A.; SILVA, M. M. S.; EUCLYDES, M. P.; TINÔCO, A. L. A. Conhecimento sobre aleitamento materno de puérperas atendidas em dois hospitais de Viçosa , Minas Gerais. Revista Nutrição, Campinas, vol 15(1): 29-35, jan-abr, 2002.

REA, M. F. Reflexões sobre a amamentação no Brasil: de como passamos a 10 meses de duração. Caderno Saúde Pública, Rio de Janeiro, vol. 19 (Supl. 1): S37-S45, 2003.

SHARON, J. Imunologia Básica, Ed. Guanabara Koogan, RJ, 267p, 1998. 
ANEXO 1 
Folder do Hospital Amigo da Criança

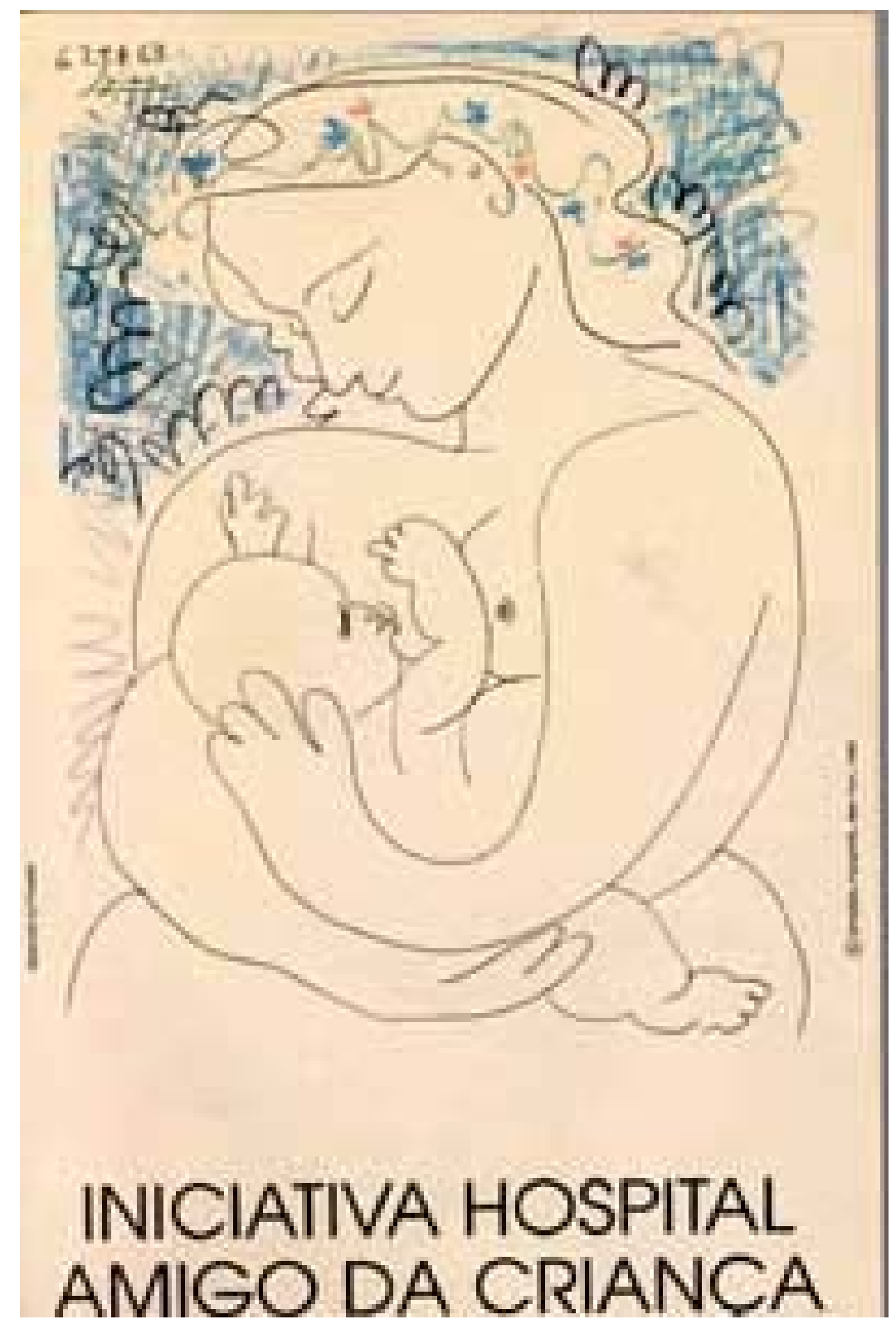


ANEXO 2 
Os dez passos daalimentação saudável para crianças brasileiras menores de dois anos
PASSO1-Dar somenteleite matemoatéosseismeses, sem oferecer água, chás ou quaisquer outros alimento.

O leite materno contém tudo o que a criança neoessita até os 6 meses de idade, inclusive água, além de proteger contra infeç̧ồes.

A criança que reoebe outros alimentos além do leite matemo antes dos seis meses, principalmente através de mamadeira, incluindo água e chás, pode adoecer mais e ficar desnutrida.

PASSO 2-A partir dos seis meses, oferecer de forma lenta egradual outrosalimentos, mantendo o leite matemo atéos dois anos de idade oumais.

A partir dos seis meses, o organismo da criança jả está preparado para reoeber alimentos diferentes do leite materno, que sâo chamados de alimentos complementares.

Mesmo recebendo outros alimentos, a criança deve ontinuar a mamar no peito até os dois anos ou mais, pois o kite materno continua alimentando a criança e protegendo-a contra doenças.

Com a introdução da alimentação omplementar, è importante que a criança roceba água nos intervalos das refeiçồes.

PASSO 3-A partir dosseismeses, dar alimentoscomplementares (cereais, tubérculos, carnes, leguminosas, frutas e legumes) três vezesao dia, se a criança receber leite matemo, ecinco vezesao dia, seestiver desmamada.

Se a criança está mamando no peito, três refeições por dia com alimentos adequados são suficientes para garantir uma boa nutrição e crescimento, no primeiro ano de vida. No segundo ano de vida, devem ser acresoentados mais dois lanches, além das trếs refeiçồes.

Se a criança não está mamando no peito, deve reoeber cinco refeiçôes ao dia oom alimentos complementares jả a partir do sexto mês.

Algumas crianças precisam ser estimuladas a comer (nunca forçadas).

PASSO 4-A alimentaçäo complementar deveser oferecida sem rigidez de horários, respeitando-se semprea vontadedacriança.

Crianças amamentadas no peito em live demanda desenvolvem muito colo a capacidade de autocontrole sobre a ingestão de alimentos, aprendendo a distinguir as sensaçôes de saciodade após as refeições e de fome após o jejum (periodo sem oferta de alimentos). Esquemas rigidos de alimentação interferem nesse processo de auto ontrole pela criança.

Este aprendizado prococe é fundamental na formação das diferenças nos estilos de controle de ingestão de alimentos nos primeiros anos de vida;

$\mathrm{O}$ tamanho da refeição está relacionado positivamente $\infty \mathrm{m}$ os intervalos entre as refeiçōes (grandes refeiçỗes estão associadas a longos intervalos e vice-versa).

É importante que as mães desenvolvam a sensibilidade para distinguir o desconforto do bebê por forme de outros tipos de desconforto (sono, frio, calor, fraldas mollhadas ou sujas, dor, necessidade de carinho), para que elas não insistam $\mathrm{em}$ oferecer alimentos à criança quando esta não tem fome. Sugere-se, sem esquema rigido de horário, que, para as crianças em aleitamento materno, sejam oferecidas três refeições oomplementares, uma no periodo da manhã, uma no horáio do almoço e outra no final da tarde ou no inicio da noite.

Para as crianças jả desmamadas, devem ser oferecidas três refeições mais dois lanches, assim distribuidos: no periodo da manhã (desjejum), meio da manhã (lanche), almoço, meio da tarde (segundo lanche), final da tarde ou inicio da noite (jantar).

PASSO5-A alimentaçăo complementar deveser espessa desdeo início e oferecida de colher; começar com consistência pastosa (papas / purês)e, gradativamente, aumentara sua consistência até chegar àalimentaçäo da familia.

No inicio da alimentação complementar, os alimentos oferecidos à criança devem ser preparados especialmente para ela, sob a forma de papas/purês de kgumes/oereais/ frutas. São os chamados alimentos de transição.

A partir dos oito meses, podem ser oferecidos os mesmos alimentos preparados para a familia, desde que amassados, desfiados, picados ou oortados em podaços pequenos.

Sopas e oomidas ralas/moles não forneœem energia suficiente para a criança.

Deve-se evitar o uso da mamadeira, pois a mesma pode atrapalhar a amamentação e é importante fonte de contaminação e transmissão de doenças.

Recomenda-se o uso de oopos (copinhos) para ofereoer água ou outros liquidos e dar os alimentos semi-sólidos e sólidos com prato e com a oolher. 
PASSO 6-Oferecer à criança diferentes alimentos ao dia. Uma alimentaçăo variadaé umaalimentaçăo colorida.

Desde cedo a criança deve acostumar-se a comer alimentos variados.

Só uma alimentação variada evita a monotonia da dieta e garante a quantidade de ferro e vitaminas que a criança necessita, mantendo uma boa saúde e crescimento adequados.

O ferro dos alimentos é melhor absorvido quando a criança recebe, na mesma refeição, carne e frutas ricas em vitamina $C$.

A formação dos hábitơs alimentares é muito importante e começa muito cedo. É comum a criança aceitar novos alimentos apenas após algumas tentativas $\mathrm{e}$ não nas primeiras. $\mathrm{O}$ que pode parecer rejeição aos novos alimentos é resultado do processo natural da criança em conhocer novos sabores e texturas $\mathrm{e}$ da própria evoluçâo da maturaçào dos reflexos da criança.

Os alimentos devem ser oferecidos separadamente, para que a criança aprenda a identificar as suas cores e sabores. Colocar as porçóes de cada alimento no prato, sem misturá-las.

PASSO 7-Estimular o consumo diário de frulas, verduras e legumes nas refeicōes. As crianças devem acostumar-se a comer frutas, verduras e legumes desck codo, pois esses alimentos são importantes fontes de vitaminas, cálcio, ferro e fibras.

Para temperar os alimentos, recomenda-se o uso de odbola, alho, óleo, pouco sal e ervas (salsinha, cebolinha, ocentro).

PASSO 8 - Evitar açúcar, café, enlatados, frituras, refrigerantes, balas, salgadinhos eoutras guloseimas, nos primeiros anos de vida. Usar sal com moderaçăo.

Açúcar, sal e frituras devem ser consumidos com moderação, pois o seu excesso pode trazer problemas de saúde no futuro. $\mathrm{O}$ açúcar somente deve ser usado na alimentação da criança após um ano de idade.

Esses alimentos não são bons para a nutrição da criança e ompetem oom alimentos mais nutritivos. Deve-se evitar alimentos muito condimentados (pimenta, mostarda, "catchup", temperos industrializados).

PASSO9-Cuidar da higiene no preparo emanuseio dos alimentos; garantir o seu ammanenamento econservaçäoadequados.

Para uma alimentação saudável, deve-se usar alimentos frescos, maduros e em bom estado de conservação.

Os alimentos oferecidos às crianças devem ser preparados pouco antes do consumo; nunca oferecer restos de uma refeição.

Para evitar a contaminação dos alimentos e a transmissão de doenças, a pessca responsável pelo preparo das refeiçôes deve lavar bem as mãos e os alimentos que serão consumidos, assim como os utensilios onde serão preparados e servidos.

Os alimentos devem ser guardados em local fresco e protegidos de insetos e outros animais.

Restos de refeições que a criança recusou nào devem ser oferecidos novamente.

PASSO 10-Estimular a criança doente e convalescente a se alimentar, oferecendo sua alimentaçäo habitual eseus alimentos preferidos, respeitando a sua aceiltação.

As crianças doentes, em geral, têm menos apetite. Por isso, devem ser estimuladas a se alimentar, sem, no entanto, serem forçadas a comer.

Para garantir uma melhor nutrição e hidratação da criança doente, aconselha-se oferecer os alimentos de sua preferéncia, sob a forma que a criança melhor aceite, $\mathrm{e}$ aumentar a oferta de liquidos.

Para a criança œom pouøo apetite, ofereoer um volume menor de alimentos por refeição e aumentar a frequiência de oferta de refeiçôes ao dia.

Para que a criança doente alimente-se melhor, é importante sentar-se ao lado dela na hora da refeição e ser mais flexivel oom horinios e regras.

No periodo de convalesøença, o apetite da criança encontra-se aumentado. Por isso, rocomenda-se aumentar a oferta de alimentos nesse periodo, acrescentando pelo menos mais uma refeição nas 24 horas.

Enquanto a criança come com sua própria colher, a pessca responsável pela sua alimentação deve ir oferecendo-lhe alimentos com o uso de outra.
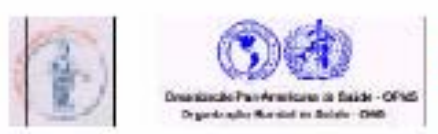
ANEXO 3 


\section{MANUAL TÉCNICO DA REDE NACIONAL DOS BANCOS DE LEITE HUMANO}

\section{DEFINIÇÃO E CONCEITO}

Banco de Leite Humano - centro especializado obrigatoriamente vinculado a um hospital materno e ou infantil, responsável pela promoção do incentivo ao aleitamento materno e execução das atividades de coleta, processamento e controle de qualidade de colostro, leite de transição e leite humano maduro, para posterior distribuição, sob prescrição do médico ou de nutricionista.

- Banco de Leite de Referência - unidade destinada a desempenhar funções comuns nos Bancos de Leite, treinar, orientar e capacitar recursos humanos, desenvolver pesquisas operacionais, prestar consultoria técnica e dispor de um laboratório credenciado pelo Ministério da Saúde.

- Banco de Leite de Empresa - unidade vinculada aos Serviços de Saúde de Empresas, onde trabalham mulheres em idade fértil, objetivando à promoção do aleitamento materno, a coleta, processamento e distribuição de leite humano, prioritariamente a filho da nutriz funcionária.

- Posto de Coleta - unidade destinada à promoção do aleitamento materno, à coleta de colostro, leite de transição e do leite maduro, dispondo de área física e de todas as condições técnicas necessárias, podendo ser fixo ou móvel, mas obrigatoriamente vinculado a um Banco de Leite Humano.

- Colostro Humano - primeiro produto da secreção láctica da nutriz, até 07 dias após o parto, em média.

- Leite Humano de Transição - produto intermediário da secreção láctica da nutriz, entre colostro e leite maduro, obtido entre o $7^{\circ}$ e $15^{\circ}$ dia pós-parto, 
em média.

- Leite Humano Maduro - produto de secreção láctica da nutriz, livre de colostro, obtido a partir do $15^{\circ}$ dia pós-parto, em média.

- Produtos Crus - os produtos acima são assim denominados quando não recebem qualquer tratamento.

- Produtos Processados - os produtos acima passam a ser assim denominados quando submetidos a tratamento térmico, seguidos ou não de liofilização.

- Doadoras - nutrizes sadias que apresentam secreção láctica superior às necessidades de seu filho e que se dispõem a doar o excesso, clinicamente comprovado, por livre e espontânea vontade.

- Consumidores (ou Receptores) - lactentes que necessitam dos produtos do Banco de Leite.

- Coleta - extração do excesso de secreção láctica das nutrizes.

- Embalagem - recipiente no qual o produto é assepticamente acondicionado e que garante a manutenção de seu valor biológico.

- Pasteurização - tratamento aplicado ao leite, que visa a inativação térmica de 100\% das bactérias patogênicas e 90\% de sua flora saprófita, através de um binômio temperatura/tempo de 62,5\% com 30 minutos ou equivalente, calculado de modo a promover equivalência a um tratamento 15 D para inativação térmica da Coxiella Burnetti.

- Liofilização - processo e conservação aplicável aos produtos descritos nestas Normas, através da redução do seu teor de água, por sublimação, até uma unidade final de $4-5 \%$.

- Reconstituição - reincorporação de água dos produtos liofilizados, de modo a atingir o nível original do produto "in natura".

- Pré-Estocagem - condição temporária na qual o produto é mantido sob congelamento, antes de chegar ao Banco de Leite. 
- Estocagem - condições sob as quais o produto, devidamente acondicionado, é mantido até o ato do consumo.

- Período de Estocagem - limite de tempo em que o produto será armazenado, sob condições pré-estabelecidas.

- Normas Higiênico-Sanitárias - regras estabelecidas para orientar e padronizar procedimentos, tendo por finalidade assegurar a qualidade do processo, sob o ponto de vista de saúde pública.

- Aditivos - toda e qualquer substância adicionada ao produto, de modo intencional ou acidental.

- Flora Microbiana - microrganismos presentes nos produtos aqui descritos, sendo considerada primária aquela decorrente da contaminação do interior das mamas, e secundária, a que se origina de agentes externos.

- Adulteração - os produtos descritos neste documento serão considerados adulterados quando contiverem substâncias tóxicas ou deletérias, acima dos níveis de tolerância estabelecidos pelo órgão de saúde pública.

- Sanitização - aplicação de um método efetivo de limpeza, visando a destruição de elementos patogênicos e de outros organismos.

- "Pool" - produto resultante da mistura de doações.

- Rótulo - identificação impressa ou litografada, bem como os dizeres pintados ou gravados, por pressão ou decalcação, aplicados sobre a embalagem.

COLETA DE LEITE

\section{Coleta de Leite Humano Ordenhado}

A coleta representa a primeira etapa na manipulação do leite humano ordenhado e é composta por elenco de atividades que vão desde a 
massagem e ordenha até a pré-estocagem do produto. A coleta pode ser realizada por expressão manual ou com auxílio de bombas, manuais ou elétricas, em salas ou recintos apropriados, localizados nos Bancos de Leite, em enfermarias, nos postos de coleta ou nas residências.

As coletas realizadas em enfermarias e domicílios demandam um maior rigor quando comparadas às efetuadas em recinto apropriado e exclusivo para este fim, tendo em vista as diferentes formas de contaminação e a maior dificuldade de controle.

Os funcionários do Banco de Leite Humano devem ser devidamente treinados e as doadoras previamente orientadas dentro dos padrões técnicos e higiênico-sanitários detalhados a seguir:

\section{Ambiente-Local}

- Possuir piso, paredes teto e divisórias revestidos com material impermeável de modo a facilitar as operações de limpeza e sanitização;

- Estar localizado de forma adequada, afastado de outras dependências que possam causar prejuízos à obtenção higiênica do leite. Neste particular, é importante evitar os cruzamentos de fluxos;

- Ser limpo e sanitizado rigorosamente antes de cada turno de trabalho;

- Em se tratando de coleta domiciliar, orientar a doadora para procurar um local tranqüilo, evitando aqueles que tragam risco à qualidade microbiológica do LHO, à semelhança de sanitários e/ou dependências onde se encontrem animais domésticos;

- Com referência às enfermarias, recomenda-se que todos os princípios observados para a coleta no BLH e no domicílio sejam observados, na medida do possível para estas unidades. 


\section{Ordenha}

- Dispor sobre a mesa o material esterilizado;

- Colocar a tampa do frasco na mesa com a parte estéril para cima;

- Desprezar os primeiros jatos em um pequeno frasco ou em um pano limpo, para reduzir os contaminantes microbianos e assim melhorar a qualidade sanitária do leite humano ordenhado;

- Após o término da ordenha, fechar e identificar o frasco de acordo com os critérios de rotulagem utilizados;

- Quando da utilização de bombas manuais, cuidar para que, toda vez que o receptáculo estiver cheio, seja vertido o leite para o frasco, pressionando sempre a pêra de borracha para evitar que o leite entre em contato direto com a mesma.

\section{Ordenha no Domicílio}

- Esta operação deve ser encarada com rigor absoluto, no sentido de garantir a qualidade sanitária do produto, devido às diferentes formas de contaminação que podem ocorrer;

- Fazer higienização das mãos com água e sabão e escovação das unhas imediatamente antes de cada ordenha. Explicar à doadora que esta conduta evita o risco de contaminação do leite;

- Secar as mãos e mamas com toalha limpa;

- Evitar conversar durante a ordenha ou utilizar uma fralda sobre o nariz. Isto torna-se obrigatório se a mãe estiver resfriada;

- Ao promover nova coleta, para completar o volume de LHO no frasco utilizado, empregar um copo de vidro previamente submerso em água fervente por 15 minutos e resfriado, colocando o leite recémcoletado, sobre aquele que estiver sendo mantido no interior do 
congelador;

- Explicar a maneira correta de pré-estocar o leite e seu prazo de validade, ou seja: refrigerador, por 24 horas; congelador da geladeira ou freezer, por 15 dias;

- Salientar que o frasco deverá estar bem vedado para evitar que o leite absorva odores e outros voláteis nocivos.

\section{Ordenha nas Enfermarias}

- Como foi visto anteriormente, as coletas realizadas em enfermarias e domicílios, demandam cuidados adicionais quando comparadas às efetuadas em recinto apropriado e exclusivo para este fim. Isto advém das diferentes formas de contaminação e à maior dificuldade de controle aí existentes:

- O ideal seria que em todas as enfermarias de puérperas existisse uma pequena sala para atendimento às intercorrências da lactação e coleta de LHO. Como na maioria dos hospitais não se consegue um espaço para essa atividade, o que se recomenda é que todos os princípios observados para a coleta no BLH e no domicílio sejam observados também no interior das enfermarias.

\section{Equipamentos e Utensílios}

- Lavar e esterilizar previamente todo o material, utensílios e equipamentos que entram em contato com o leite, antes da utilização, para cada doadora.

- Entregar frascos esterilizados e rotulados à doadora;

\section{Doadora}

- As doadoras são por definição, mulheres sadias que apresentam secreção láctica superior às exigências de seus filhos e que se 
dispõem a doar o excedente por livre e espontânea vontade.

- Fazer anamnese e exame físico da doadora para levantar os aspectos clínicos relevantes. Serão inaptas para a doação, a critério médico, as nutrizes que sejam portadoras de moléstias infectocontagiosas ou que se encontrem em risco nutricional.

- Orientar a doadora para que retire a blusa, sutiã, anéis, pulseiras, relógios, etc, visando reduzir a contaminação microbiana.

- Calçar ou não sapatilha ou correlatos, de acordo com a regulamentação da instituição. Esta conduta é recomendada visando manter a higienização do ambiente.

- Solicitar à doadora para lavar as mãos e antebraços e usar escovas de unha individuais para remover as sujidades, fazendo escovação cuidadosa com uso de sabão e sob água corrente. Se possível, a doadora deverá manter as unhas aparadas durante o período da doação.

- Solicitar à doadora para secar as mamas e mãos com toalha individual, fechar a torneira com a própria toalha, evitando assim a recontaminação das mãos a partir da torneira.

Obs: Ao lavar as mamas e mamilos não utilizar sabão, pois este resseca os mamilos, predispondo-os a fissuras.

\section{Funcionários}

- Os funcionários que trabalhem em Bancos de Leite Humano, devem ser submetidos a exames periódicos de saúde.

- A periodicidade dos exames de saúde deve ser estabelecida pela equipe de saúde do BLH, ouvida a autoridade sanitária competente.

- A ação fiscalizadora, sob este item, será exercida pela Secretaria de Saúde através da Vigilância Sanitária responsável pela localidade 
onde se encontra o BLH.

- Os funcionários devem lavar cuidadosamente as mãos com água e sabão, escovando as unhas e friccionando álcool a 70\% durante 30 segundos, a fim de reduzir a carga microbiana de suas mãos após o enxágüe. Poderão vestir o avental ou não, de acordo com a regulamentação da instituição, bem como colocar gorro e máscara.

- Devido ao problema das doenças infecto-contagiosas, e principalmente no que se refere a pacientes aidéticas, recomenda-se o uso de luvas de procedimento pelos funcionários.

\section{TRANSPORTE}

\section{Do Local de Coleta para o BLH}

- Os produtos devem ser transportados do local de coleta ao Banco de Leite em embalagens adequadas e específicas para esta finalidade.

- Colocar os frascos em caixas isotérmicas, preferencialmente revestidas com PVC, contendo "gelo reciclável" em quantidade proporcional ao número de frascos de LHO.

- O gelo comum só deverá ser utilizado quando o leite estiver fluído, pois representa uma fonte de calor para o leite congelado. O "gelo reciclável" propicia temperatura mais baixa, o que garante a manutenção do leite congelado.

- Ao manter o leite a baixas temperaturas, estaremos evitando a proliferação de microrganismos, resultando em um produto de melhor qualidade. 


\section{Do BLH para local de Consumo}

- Na impossibilidade de se dispor de "gelo reciclável", o leite congelado deve ser transportado na caixa isotérmica sem gelo.

- O produto transportado deve chegar ao consumidor com as mesmas características que possuía ao sair do BLH.

Obs: O gelo reciclável pode ser preparado no próprio BLH, utilizando para esta finalidade: $200 \mathrm{ml}$ de glicerina líquida, $200 \mathrm{ml}$ de álcool e $600 \mathrm{ml}$ de água. Esta mistura, após homogeneizada, deve ser colocada em congelador ou freezer por um período aproximado de 12 horas, tempo suficiente para congelar e entrar em equilíbrio térmico.

\section{SELEÇÃO E CLASSIFICAÇÃO DO LEITE}

\section{Degelo}

\section{Seleção Inicial}

\section{Crematócrito}

A técnica do crematócrito, originalmente descrita por LUCAS e colaboradores em 1978, foi adaptada e testada com êxito na rotina operacional dos BLH no país.

O crematócrito é semelhante ao micro-hematócrito, devendo-se utilizar leite em lugar do sangue. Após a centrifugação dos capilares por 15 minutos, ocorre a separação do creme e soro do leite, o creme ocupa a parte posterior do capilar e corresponde à fração de coloração mais densa. O soro, de aspecto "mais ralo", fica abaixo do creme. Com auxílio de uma régua milimetrada deve-se medir o comprimento da coluna de creme $(\mathrm{mm})$ e da coluna total do produto (coluna de creme + coluna de soro, expressos em $\mathrm{mm}$ ). De posse destes valores, empregando as fórmulas abaixo, obtém-se:

Teor de coluna $=\underline{\text { Coluna de Creme }(\mathrm{em} \mathrm{mm}) \times 100}$

(\%) Coluna total de produto (em $\mathrm{mm}$ ) 
Teor de gordura $=\underline{\text { Teor de } \text { creme }(\%)-0,59}$

(\%) 1,46

Energia $($ Kcal/litro $)=66,8 \times$ Teor de creme $(\%)+290$

\section{Acidez Dornic}

A medida da acidez do leite humano em graus Dornic $\left({ }^{0} D\right)$ pode ser utilizada para o controle físico-químico de qualidade.

Utiliza-se nesta técnica uma solução tampão de $\mathrm{NaOH}(0,11 \mathrm{~N})$ e a fenolftaleína, como indicador do ponto de viragem do pH ácido para neutro.

Após pipetar $1 \mathrm{ml}$ do leite a ser testado, adiciona-se 1 gota de fenolftaleína. Com o uso do acidímetro, graduado em $\mathrm{mm}$, a solução de hidróxido de sódio é adicionada ao leite com fenolftaleína, gota a gota, até obter-se uma mudança na coloração do meio (que se torna róseo-claro com a mudança do $\mathrm{pH}$ ). Neste momento, faz-se a leitura da coluna milimetrada do acidímetro. $\mathrm{O}$ volume de $\mathrm{NaOH}$ gasto para neutralizar o meio corresponde, em milímetros, aos graus Dornic de acidez daquele leite testado. Se forem gastos $3 \mathrm{~mm}$ de base para a neutralização, a acidez deste leite é de $3^{\circ} \mathrm{D}$. Ensaios preliminares apontam para um valor médio de acidez em torno de 3 a 4 graus, podendo considerar como aceitáveis valores menores que $8^{\circ} \mathrm{D}$.

\section{ACONDICIONAMENTO E EMBALAGEM}

- Certificar-se que os frascos para reenvase foram corretamente esterilizados. Descartar os que apresentarem sujidades no interior, observando ainda o prazo de validade da esterilização.

- Os produtos que chegarem congelados devem ser submetidos a degelo prévio.

- Acender o campo de chama, que poderá ser obtido com lamparina a 
álcool ou bico de bunsen, evitando desta forma a contaminação do produto.

- Proceder o reenvase em campo de chama, segundo volumes adotados pelo BLH

\section{PASTEURIZAÇÃO}

- Regular o banho-maria à temperatura de pasteurização. A temperatura do banho-maria deverá ser suficiente para aquecer o LHO a $62,5^{\circ} \mathrm{C}$.

- Certificar-se que o banho-maria estabilizou-se à temperatura adotada, através de um termômetro.

- Colocar os frascos no interior do banho-maria. O nível da água deve ser superior ao do produto no interior dos frascos. Recomenda-se pasteurizar, ao mesmo tempo, frascos que contenham volumes aproximados.

- Aguardar o tempo de pré-aquecimento, que deverá ser pré-estabelecido em função das condições de processamento. $O$ tempo de pré-aquecimento varia em função do número de frascos e do volume de LHO.

- Marcar 30 minutos imediatamente após o término do pré-aquecimento.

- Retirar os frascos do banho-maria e promover o resfriamento.

- O resfriamento dos frascos deverá ser feito por imersão em água a $5^{\circ} \mathrm{C}$ (água + gelo). Este procedimento visa cessar as perdas do produto pelo calor residual.

- Coletar amostras para o controle de qualidade microbiológico.

\section{ROTULAGEM}

- Todo produto processado/estocado será obrigatoriamente rotulado. 
- Os rótulos deverão conter as seguintes informações: classificação, local e data de coleta, condições de pré-estocagem, identificação da doadora, dados sobre o RN e validade. No caso de informatização, o rótulo poderá conter apenas localizadores que permitam identificar estas informações.

\section{ESTOCAGEM}

- É vedada a estocagem de LHO com outros produtos hospitalares.

- O tipo clássico de estocagem, após o tratamento de pasteurização, é o congelamento por até 6 (seis) meses em freezers.

- Efetuar rigoroso controle de temperatura dos freezers para evitar flutuações prejudiciais à manutenção da qualidade do produto.

\section{DISTRIBUIÇÃO}

O LHO deve ser distribuído de acordo com os critérios estabelecidos pela Portaria MS-322/88.

Normalmente são selecionados como receptores os lactentes que apresentam uma ou mais das indicações que se seguem:

- Prematuros e Recém-nascido de baixo peso que não sugam;

- Recém-nascidos infectados, especialmente com entero-infecções;

- Portadores de deficiências imunológicas;

- Portadores de diarréia protraída;

- Casos excepcionais, a critério médico;

- Portadores de alergia a proteínas heterólogas. 


\section{CONTROLE DE QUALIDADE}

\section{Aspectos Gerais:}

O objetivo do controle de qualidade é conseguir um produto com qualidade preservada, boa e constante, desde a coleta até o consumo, a baixo custo e com o mínimo de risco para a saúde do consumidor.

A qualidade dos produtos processados, estocados e distribuídos pelos Bancos de Leite deve ser fruto de um esforço inteligente e constante em todas as etapas até a distribuição. A qualidade tem um significado amplo, incluindo as características responsáveis pelo valor biológico do produto e a segurança para o consumidor, sob o ponto de vista de saúde pública. A literatura define qualidade como um termo subjetivo, capaz de assumir diferentes significados para diferentes pessoas, em diferentes situações. Vários autores agregam a esta definição conceitos tais como: "adequado ao uso, atendimento às necessidades dos clientes, estar de acordo com as especificações, satisfação do cliente, etc.". Assim, a qualidade do leite humano ordenhado pode então ser definida como uma grandeza que resulta da avaliação conjunta de uma série de parâmetros, que incluem as características nutricionais, imunológicas, químicas e microbiológicas.

O critério para avaliar a qualidade é complexo e incorpora os planos de amostragem, os métodos de análise e os padrões de qualidade. Os padrões devem ser dinâmicos e ajustados à evolução técnica do setor, resultando em produtos cada vez melhores.

O controle de qualidade deve ser parte de um sistema integrado, que permeia todas as etapas do processo, sem restringir-se exclusivamente às análises laboratoriais. 


\section{Sistema de Controle}

O controle de qualidade pode assumir um caráter preventivo ou retrospectivo. O controle preventivo é o mais importante sob o ponto de vista operacional, uma vez que dele depende o comportamento do produto oferecido ao consumo. O controle retrospectivo objetiva determinar as origens de qualquer problema relacionado à qualidade do produto, quando não é mais passível de controle. As informações, obtidas pelo controle retrospectivo, são utilizadas para evitar futuros problemas, uma vez que permitem a identificação das causas.

A adoção de um sistema preventivo e dinâmico de controle de qualidade assume particular importância para os Bancos de Leite, pois reduz os riscos operacionais. Este controle é realizado ao longo de todo o processo e baseia-se no emprego de técnicas adequadas, a nível de:

\section{- Preparo de material}

lavagem, esterilização ou sanitização

controle das condições higiênico-sanitárias

\section{- Funcionários}

controle de saúde capacitação técnica

\section{- Doadoras}

controle de saúde orientação sobre cuidados higiênicosanitários

\section{- Condições higiênicas}

- Orientação técnica sobre a condição de coleta

- Coleta

- Seleção e Classificação

- Processamento

- Estocagem

- Distribuição

- Transporte 
A proteção e os cuidados dispensados ao leite humano devem ter início no planejamento do Banco, onde a localização e o projeto de engenharia ("layout", localização de portas e janelas, cruzamento de fluxo, tipo de piso e de parede, localização dos equipamentos, etc.), podem influir de maneira significativa na qualidade dos produtos.

Os Bancos de Leite Humano enfrentam hoje no Brasil o sério problema de certificar a qualidade de seus produtos, tanto a nível sanitário como físico-químico/nutricional. Isto porque as metodologias são caras e/ou de difícil acesso, face à sua complexidade. Há necessidade de se desenvolver e adaptar técnicas laboratoriais de fácil execução, de baixo custo, que sejam precisas e sensíveis o suficiente para serem empregadas no controle de qualidade de rotina dos BLH.

Outro fator importante a ser lembrado é a carência de informações, na literatura pertinente, sobre padrões mínimos de identidade para o leite humano ordenhado, necessários ao funcionamento do controle de qualidade.

Os problemas supra mencionados levaram ao desenvolvimento de um esforço conjunto INAN/FIOCRUZ-IFF, na busca de metodologias alternativas, seguras e compatíveis com a realidade dos BLH no Brasil. Os primeiros resultados desta iniciativa encontram-se aqui relacionados.

\section{Controle Sanitário do LHO}

Há muita controvérsia com relação aos microrganismos mais indicativos ou representativos da qualidade sanitária do leite humano ordenhado. Os contaminantes de origem fecal têm ocupado lugar de destaque nas metodologias que se fundamentam em indicadores de qualidade. Historicamente, a relação de causa e efeito no processo de transmissão de doenças relacionado às fezes foi postulada por Von Fristsch em 1880, após identificar Klebsiella sp em fezes humanas. Posteriormente, Escherich descreveu o Bacillus coli (Escherichia coli), sugerindo a sua utilização como um indicador de poluição fecal. Com o avanço do conhecimento científico, descobriu-se a ocorrência de diferentes patógenos 
nas fezes, de forma descontínua e em concentrações variáveis. Assim, inúmeros estudos foram desenvolvidos no sentido de definir um indicador para a presença destes microrganismos nas fezes do homem e dos animais de sangue quente.

Em 1982, Shardinger sugeriu que o grupo coliforme poderia ser utilizado como índice de contaminação fecal, uma vez que pode ser detectado mais facilmente que espécies de Salmonella. O cultivo dos indicadores deve ser simples, economicamente viável e seguro, minimizando a possibilidade de resultados falso-positivos. De acordo com estes critérios, os melhores indicadores de contaminação de origem fecal, direta ou indireta, têm sido os coliformes totais, coliformes fecais e $E$. coli.

A partir da metodologia clássica descrita no "Standard Methods for the Examination of Dairy Products", foi desenvolvida uma metodologia alternativa que consiste em inocular quatro alíquotas de $1 \mathrm{ml}$ cada (pipetadas independentemente, após agitação em vórtex por 15 segundos) em tubos com $10 \mathrm{ml}$ de Caldo Verde Brilhante (BGBL) a 5\% p/v, com tubos de Durhan em seu interior. Após a inoculação, os tubos devem ser incubados a 36 +/-1 C por 48 horas. A presença de gás no interior do tubo de Durhan caracteriza resultado positivo. O tubo positivo deverá ser repicado, com auxílio de alça de platina, para tubos de BGBL (concentração de $40 \mathrm{~g} / \mathrm{l})$. A presença de gás confirma a presença de microrganismos do grupo coliforme, tornando o produto impróprio para consumo.

A metodologia alternativa e a clássica não diferiram entre si, quando comparadas pelo teste de Qui-Quadrado ao nível de 5\% de probabilidade. Os coeficientes de correlação e de determinação do estudo em foco foram, respectivamente, iguais a 0.95 e 0.91 . Isto permite concluir em favor da utilização do teste alternativo em nível de rotina.

\section{Controle Físico-Químico}

A utilização de indicadores físico-químicos para controlar a qualidade do leite humano ordenhado representa uma alternativa capaz de compatibilizar o custo operacional do controle com as exigências nutricionais 
dos consumidores. Dentre as características que definem o valor nutricional do LHO, destacam-se o teor de gordura e o conteúdo energético.

A técnica do crematócrito, originalmente descrita por LUCAS e colaboradores em 1978, foi adaptada e testada com êxito na rotina operacional dos BLH no país.

O crematócrito é semelhante ao micro-hematócrito, devendo-se utilizar leite em lugar do sangue. Após a centrifugação dos capilares por 15 minutos, ocorre a separação creme e soro do leite. O creme ocupa a parte posterior do capilar e corresponde à fração de coloração mais densa. O soro, de aspecto "mais ralo", fica abaixo do creme. Com auxílio de uma régua milimetrada deve-se medir o comprimento da coluna de creme $(\mathrm{mm}) \mathrm{e}$ da coluna total do produto (coluna de creme + coluna de soro, expressos em $\mathrm{mm}$ ). De posse destes valores e empregando as fórmulas abaixo, obtém-se:

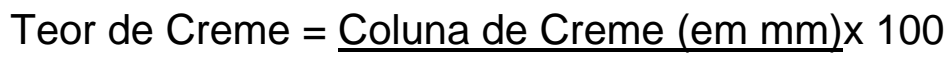

(\%) Coluna total de produto (em $\mathrm{mm}$ )

Teor de Gordura $=\underline{\text { Teor de Creme (\%) }-0.59}$

(\%) 1.46

Energia $($ Kcal/Litro $)=66.8 \times$ Teor de Creme $(\%)+290$

Por fim, cabe ressaltar que o Programa Nacional de Incentivo ao Aleitamento Materno - PNIAM, vem promovendo o desenvolvimento de estudos na busca de metodologias alternativas para o controle de qualidade de rotina do BLH em nível nacional. O Instituto Fernandes Figueira FIOCRUZ, na condição de Centro de Referência, vem trabalhando na obtenção de soluções viáveis a estes problemas 